\title{
Assessment of Open Defecation among Residents of Lagos West Senatorial District, Lagos State, Nigeria
}

\author{
*OLU, Joshua ${ }^{1}$, YUSUF, Hajara 0. ${ }^{2}$, OJO Elizabeth $0 .{ }^{2}$, AJIBULU Oluyomi.O \\ ${ }^{1}$ Faculty of Environmental Science, Nasarawa State University, Keffi \\ ${ }^{2}$ National Biotechnology Development Agency, Environmental Biotechnology and Bio conservation Department, \\ Along Musa Yar'adua Expressway, Airport Road, Lugbe, Abuja,
}

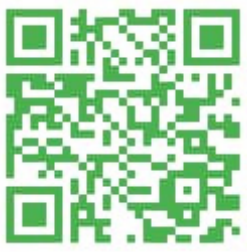

This study is an observational assessment of open defecation practices carried out from "Mile 2" in Amuwo Odofin local government area to Okokomaiko in Ojo local government area along Badagry express way in Lagos west senatorial district of Lagos State, Nigeria. A well-structured questionnaire was administered to 250 respondents to obtain the data used in this study. Male respondents were $57.2 \%$ while $42.8 \%$ were female. The respondents' educational background shows that $46 \%$ finished from secondary school while $16.4 \%$ did not attend school. The educational status of the respondents and the usage of modern toilets rather than open defecation was found to be significant atX2 $(5, N=250)=11.221, p=0.047$. A significant difference was observed between the respondents attitudes towards open defecation and their gender, for Male $(M=7.27, S D=2.220)$ and Female $(M=7.85$, $\mathrm{SD}=1.500) ; \mathrm{t}(248)=-2.138, \mathrm{p}=0.034$. The relationship between accessibility to a hygienic toilet and ending of open defecation among respondents was also significant at $\chi 2(1, N=250)=20.489, p<0.05$. The practice of open defecation was found not to be safe and was due to the lack of access to hygienic toilet facilities in the study area. Poverty level and lack of high statutory education are some of the major factors that contribute to the open defecation practices.

Keywords: Defecation, Environment, Health, Hygiene, Open, Residents

How to Cite: Olu, J., Yusuf, H.O, Ojo, E.O \& Ajibulu, O.O. (2022). Assessment of Open Defecation among Residents of Lagos West

Senatorial District, Lagos State, Nigeria. Environ. Stud. J. 1(1), 1-13. https://doi.org/10.36108/esj/2202.10.0110

\section{INTRODUCTION}

In the attainment of sustainable development and poverty reduction, good sanitation practices are very vital (Alhassan and Anyarayor, 2018). Practicing of good hygiene plays a greater role in disease prevention and control, as it relates to waterborne diseases and sanitation in environmental public health (Gbadegesin and Akintola, 2020). The targets set for the attainment of Millennium Development Goals (MDGs), were never achieved resulting to 2.5 billion people lacking access to good sanitation facilities like flush latrine and this came to bear that a population of 892 million people in the world are still practicing open defecation (Saleem et al., 2019). United Nations General Assembly expressed concerns over the persistence of open defecation (OD) in the Global South in an attempt to achieve the Sustainable Development Goals (SDGs) set for 2030 (Jain et al., 2020). 
Practicing of defecation outside rather than the use of a toilet facility is termed open defecation (Gbadegesin and Akintola, 2020). The non-usage of toilet or unavailability of toilet facility gave rise to the alternatives such as the usage of fields, uncompleted buildings, refuse dump sites, road sides gutter, streets canals, rivers, streams forests, etc. (Clansen et al., 2014).

The health risks from open defecation practices have been linked to human excrement (Cairncross et al., 2010).Reports from WHO show that in low and middle income countries, about 1.8 million people suffer from severe trachoma (WHO, 2017a), and breeding on human excreta by flies is said to be the causative agent of visual impairment that can be transmitted through the eye discharge of an infected person (Emerson et al., 2001). More than 200 million people worldwide are estimated to have been infected with schistosomias is (snail fever) (WHO, 2017b), This is a parasitic disease that is transmitted by freshwater snails and spreading the infection in humans is through skin contact with an infected freshwater snails or consumption of contaminated water snails (Colley et al., 2014). The issue of open defecation affects the environment and women are more vulnerable and often more at risk of experiencing urinary tract infection (Gabriella, 2012).

In most rural communities in Nigeria, the lack of hygienic and unhealthy practices of environmental health contributed to the prevalence of open defecation practices. The cultural beliefs of some people deprive them from accepting the use of the toilet facility as a "new" way of sanitation (Gbadegesin and Akintola, 2020). In rural communities in Nigeria, people tend to derive joy in defecating openly in streams, rivers and lagoons with the belief that water will wash it away whereas, their drinking water, and water for cooking and washing of clothes are from the same source, thereby denying such communities of self-access to clean water as well as habitation in a healthy environment (Ngwu, 2017). This has become a habitual practice or an act they grew up with which is now perceived as a normal practice in the community. Defecating in an open space is a normal daily routine which they have accepted as a norm and practice of their forefathers and forms part of their way of life from childhood. To them, the practice of open defecation remains their preferred option even if a toilet facility is made available to them (Connell, 2014).

In Nigeria, households that have the least practice of open defecation are those that are educated beyond secondary school (Abubakar, 2018). It can be said that education plays a vital role in enlightening the citizens regarding health and environmental threats associated with open defecation.

Open defecation affects the groundwater and results in filthy and unhealthy environments (Tambekar et al., 2012). It also results in the contamination of the local environment with human feces causing air pollution and environmental health related diseases. This practice of open defecation around the surrounding suburbs of beaches has polluted the beaches and resulted in a decrease in the potential tourist attraction to the area (Abubakar and Dano, 2018).

With Nigeria ranking top in the world as the country with most open defecation arenas, many public places in Lagos appears to have received very little attention with this menace. This study aimed at observational assessment of open defecation practices carried out from "Mile 2" in Amuwo Odofin local government area to Okokomaiko in Ojo local government area along Badagry expressway in Lagos west senatorial district of Lagos State, Nigeria.

\section{METHODOLOGY}

\section{Study area}

The study was carried out from "Mile 2" in Amuwo Odofin Local Government area to Okokomaiko in Ojo Local Government area along Badagry expressway in the Lagos west senatorial district. Thirteen different spots (as indicated in Table 1) where open defecation was promiscuously practiced were focused on. 
Table 1: Open defecation Location along Badagry road, Lagos, Nigeria

\begin{tabular}{cccc}
\hline & Location & \multicolumn{2}{c}{ GPS Coordinates } \\
\cline { 3 - 4 } $\mathrm{S} / \mathrm{N}$ & Areas & Latitude & Longitude \\
\cline { 3 - 4 } 1 & Mile 2 & $6^{\circ} 27^{\prime} 36^{\prime} \mathrm{N}$ & $3^{\circ} 18^{\prime} 3^{\prime} \mathrm{E}$ \\
2 & Maza-Maza & $6^{\circ} 27^{\prime} 35^{\prime} \mathrm{N}$ & $3^{\circ} 17^{\prime} 12^{\prime} \mathrm{E}$ \\
3 & First gate & $6^{\circ} 27^{\prime} 34^{\prime} \mathrm{N}$ & $3^{\circ} 17^{\prime} 10^{\prime} \mathrm{E}$ \\
4 & Agboju & $6^{\circ} 27^{\prime} 26^{\prime} \mathrm{N}$ & $3^{\circ} 16^{\prime} 13^{\prime} \mathrm{E}$ \\
5 & Alakija & $6^{\circ} 27^{\prime} 19^{\prime} \mathrm{N}$ & $3^{\circ} 15^{\prime} 19^{\prime} \mathrm{E}$ \\
6 & Dantata & $6^{\circ} 27^{\prime} 25^{\prime} \mathrm{N}$ & $3^{\circ} 14^{\prime} 27^{\prime} \mathrm{E}$ \\
7 & Abule Ado & $6^{\circ} 27^{\prime} 34^{\prime} \mathrm{N}$ & $3^{\circ} 13^{\prime} 45^{\prime} \mathrm{E}$ \\
8 & Ilepo/Trade Fair & $6^{\circ} 27^{\prime} 34^{\prime} \mathrm{N}$ & $3^{\circ} 13^{\prime} 21^{\prime} \mathrm{E}$ \\
9 & Iyanalba & $6^{\circ} 27^{\prime} 33^{\prime} \mathrm{N}$ & $3^{\circ} 12^{\prime} 55^{\prime} \mathrm{E}$ \\
10 & Alabarago & $6^{\circ} 27^{\prime} 41^{\prime} \mathrm{N}$ & $3^{\circ} 12^{\prime} 8^{\prime} \mathrm{E}$ \\
11 & PPL & $6^{\circ} 27^{\prime} 51^{\prime} \mathrm{N}$ & $3^{\circ} 11^{\prime} 52^{\prime} \mathrm{E}$ \\
12 & Cassidy & $6.467289 \mathrm{~N}$ & $3.192305 \mathrm{E}$ \\
13 & Okokomaiko & $6.471111 \mathrm{~N}$ & $3.188333 \mathrm{E}$ \\
\hline
\end{tabular}

\section{Sampling size and techniques}

In this study, a multi stage sampling procedure was used in selecting the respondents. The stages are: convenience sampling procedure which the targeted population comprises of the public space users, stratification techniques targeting the population which are made up of market women and men, transporters, roadside construction workers and passers-by around the thirteen different spots (as indicated in Table 1) where open defecation was promiscuously practiced.

In this study, 250 sample size of respondents were administered the questionnaire among the population within the area of study and this was derived with equation 1 known as Kish formula as used by Buseini et al. (2019).

$. n=Z^{2} \times P(1-P) / d^{2} \quad$ Eqn. 1

Where $n$ is the sample size; $Z$ is the statistic for a level of interval (at $95 \%, Z=1.96$ ); $P$ is the population proportion, and 0.72 (the percentage of the population known to practice open defecation in the study area); and $d$ is precision which is 0.05 .

\section{Data collection}

The well structured questionnaire was used in obtaining data from respondents and this consists of three sections, section A: demographic information of the respondents, section $B$ : questions on open defecation and sites around the study area, section C: additional opinions on the cause and how to prevent open defecation practice in the study area.

\section{Data Analysis}

The data obtained from the administration of the questionnaire were cleaned and analyzed using SPSS 22.0 software and both descriptive and inferential statistics were used. The relationship between educational status of the respondents and usage of modern toilets rather than open defecation was evaluated using Chi-square at $p<0.05$. Independent $t-$ test was used in determining the relationship between the attitudes of the respondents towards open defecation and their gender at $p<0.05$. Chisquare was utilized in examining the association between accessibility to a hygienic toilet and ending of open defecation among respondents at $p<0.05$.

- 3 - 


\section{Environmental Studies Journal}

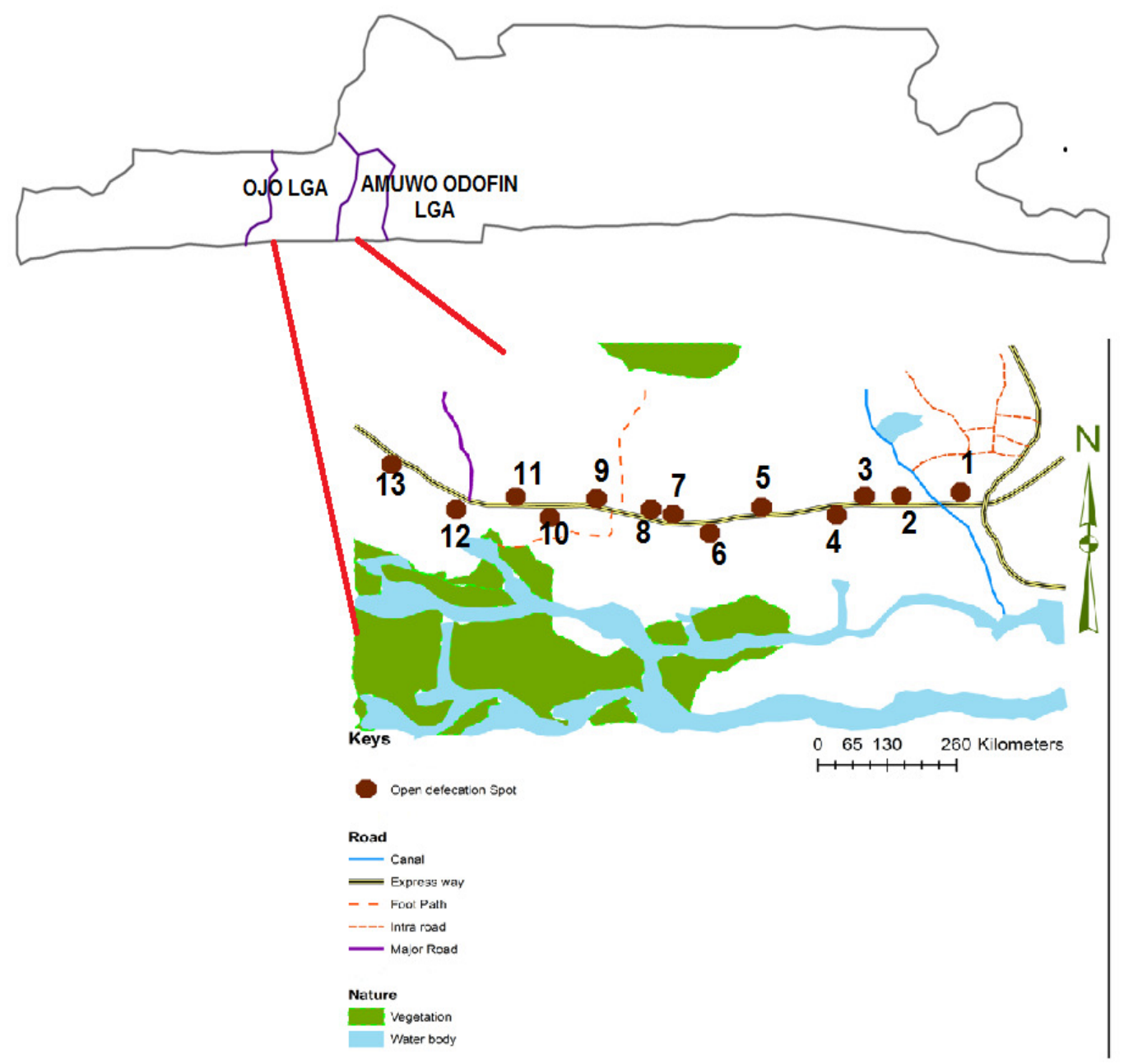

Fig. 1: Extrapolation from Lagos state map of the study area showing the open defecation spots along Badagry expressway, Lagos, Nigeria

\section{RESULTS AND DISCUSSION}

The disposal of human feces in open areas such as fields, uncompleted buildings, dump sites, road side gutters, rivers, streams and lagoon is described as open defecation, (Gbadegesin and Akintola, 2020; Clansen et al., 2014; Jones et al., 2012).

The results obtained from the study as indicated in Table 2 show that $57.2 \%$ of the respondents were male while $42.8 \%$ were female. Among the respondents, $38.8 \%$ were within the age range of 31 40 years, $32.8 \%$ were within $21-30$ years and $4.4 \%$ were above 50 years. Majority (47.2\%) of the respondents were married. The educational status of the respondents as shown in Table 2 revealed that
46\% finished from secondary school while $16.4 \%$ did not attend school. Abubakar (2018) reported in a study that households that are educated beyond secondary school are the ones that least practice open defecation. From the survey carried out by WHO in 2015, it was reported that the population proportion of those practicing open defecation seems to be decreasing with increasing levels of education (UNICEF/WHO, 2015). Therefore, the more educated members of a household are, the more informed and aware they are regarding the health and environmental threats of open defecation (Gbadegesin and Akintola, 2020).

The lower class workers made up $63.6 \%$ of the respondents as shown in Table 2.Majority of the 


\section{Environmental Studies Journal}

respondents live in one room apartment and they made up $42.8 \%$ of the total respondents in this study. It is a phenomenon that those living in abject poverty could not afford the use of improved sanitation (Njuguna and Muruka, 2017; Peprah et al., 2015). Due to the low-income levels of some people, they resort to the use of poor latrine construction materials with poor durability with zero privacy and thereby practice open defecation (Busienei et al., 2019).

As seen from Fig. 2, 31.2\% of the respondents agreed that they have been openly defecating in public space for the past two months, $23.2 \%$ claimed that they openly defecate in dug pit while $13.2 \%$ claimed they defecate openly on a dumpsite. And from Fig. 3, $54.8 \%$ of the respondents claimed that they practice open defecation due to spoilt or lack of toilet facility, $22 \%$ indicated that existing toilets are dirty or damaged while $20 \%$ attribute their open defecation practices to been pressed on the way to their destinations. The availability of a single latrine in a community results to long queue formation, especially early in the morning, which, in turn, make them embark on open defecation as an alternative (Desai et al., 2015).

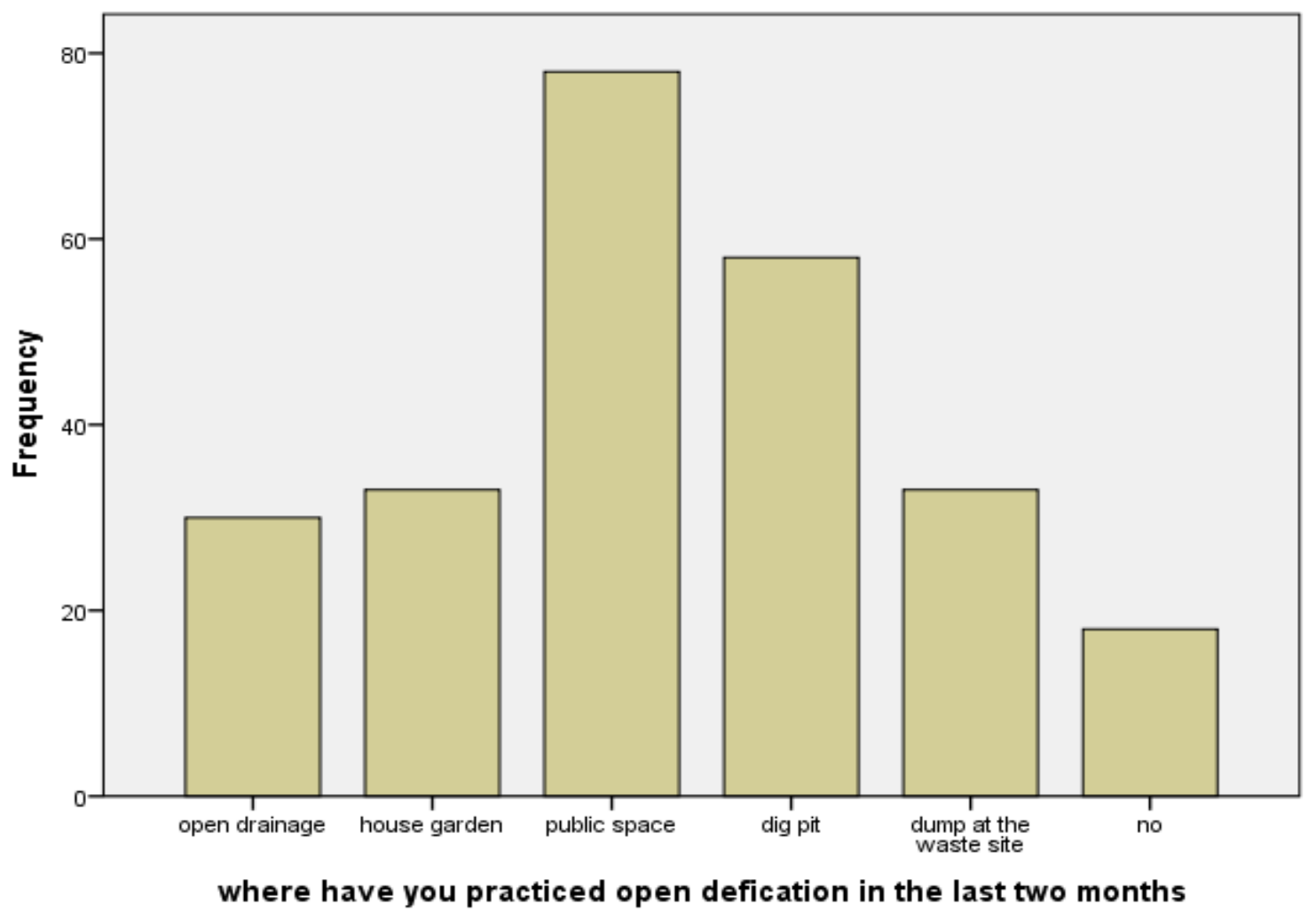

Fig. 2: Respondents opinion on where they practiced open defecation in the last two months 
Table 2: DEMOGRAPHIC CHARACTERISTICS OF RESPONDENTS

\begin{tabular}{|c|c|c|c|c|}
\hline & & Frequency (\%) & Skewness & Kurtosis \\
\hline \multirow[t]{2}{*}{ Gender } & Male & $168(57.2)$ & 0.737 & -1.468 \\
\hline & Female & $82(42.8)$ & & \\
\hline \multirow[t]{5}{*}{ Age } & $11-20$ & $34(13.6)$ & 0.323 & -0.082 \\
\hline & $21-30$ & $82(32.8)$ & & \\
\hline & $31-40$ & $97(38.8)$ & & \\
\hline & $41-50$ & $26(10.4)$ & & \\
\hline & $>50$ & $11(4.4)$ & & \\
\hline \multirow[t]{4}{*}{ Marital Status } & Single & $90(36.0)$ & 0.883 & 0.433 \\
\hline & Married & $118(47.2)$ & & \\
\hline & Divorce & $27(10.8)$ & & \\
\hline & Widow/widower & $15(6 / 0)$ & & \\
\hline \multirow[t]{4}{*}{ Ethnic } & Yoruba & $115(46.0)$ & 0.631 & -0.644 \\
\hline & Igbo & $92(36.8)$ & & \\
\hline & Hausa & $41(16.4)$ & & \\
\hline & Others & $2(0.8)$ & & \\
\hline \multirow[t]{4}{*}{ Religion } & Christianity & $152(60.8)$ & 1.373 & 2.290 \\
\hline & Islam & $88(35.2)$ & & \\
\hline & Traditional & $7(2.8)$ & & \\
\hline & Others & $3(1.2)$ & & \\
\hline \multirow[t]{6}{*}{ Education } & Not educated & $41(16.4)$ & 0.366 & 0.263 \\
\hline & Primary & $45(18.0)$ & & \\
\hline & Secondary & $115(46.0)$ & & \\
\hline & OND/NCE & $29(11.6)$ & & \\
\hline & HND/B.Sc. & $14(5.6)$ & & \\
\hline & M.Sc. \& Above & $6(2.4)$ & & \\
\hline \multirow[t]{6}{*}{ Work position } & Lower worker & $159(63.6)$ & 1.125 & -0.452 \\
\hline & Team leader & $22(8.8)$ & & \\
\hline & Supervisor & $13(5.2)$ & & \\
\hline & Manager & $10(4.0)$ & & \\
\hline & Business owner & $44(17.6)$ & & \\
\hline & Others & $2(0.8)$ & & \\
\hline \multirow[t]{4}{*}{ Accommodation } & Uncompleted building & $29(11.6)$ & -0.219 & -0.414 \\
\hline & Boys quarter & $74(29.6)$ & & \\
\hline & A room & $107(42.8)$ & & \\
\hline & Flat & $40(16.0)$ & & \\
\hline
\end{tabular}

-6 - 


\section{Environmental Studies Journal}

Website: https:www.esj.com.ng

Volume 1 Issue 1 (2022)

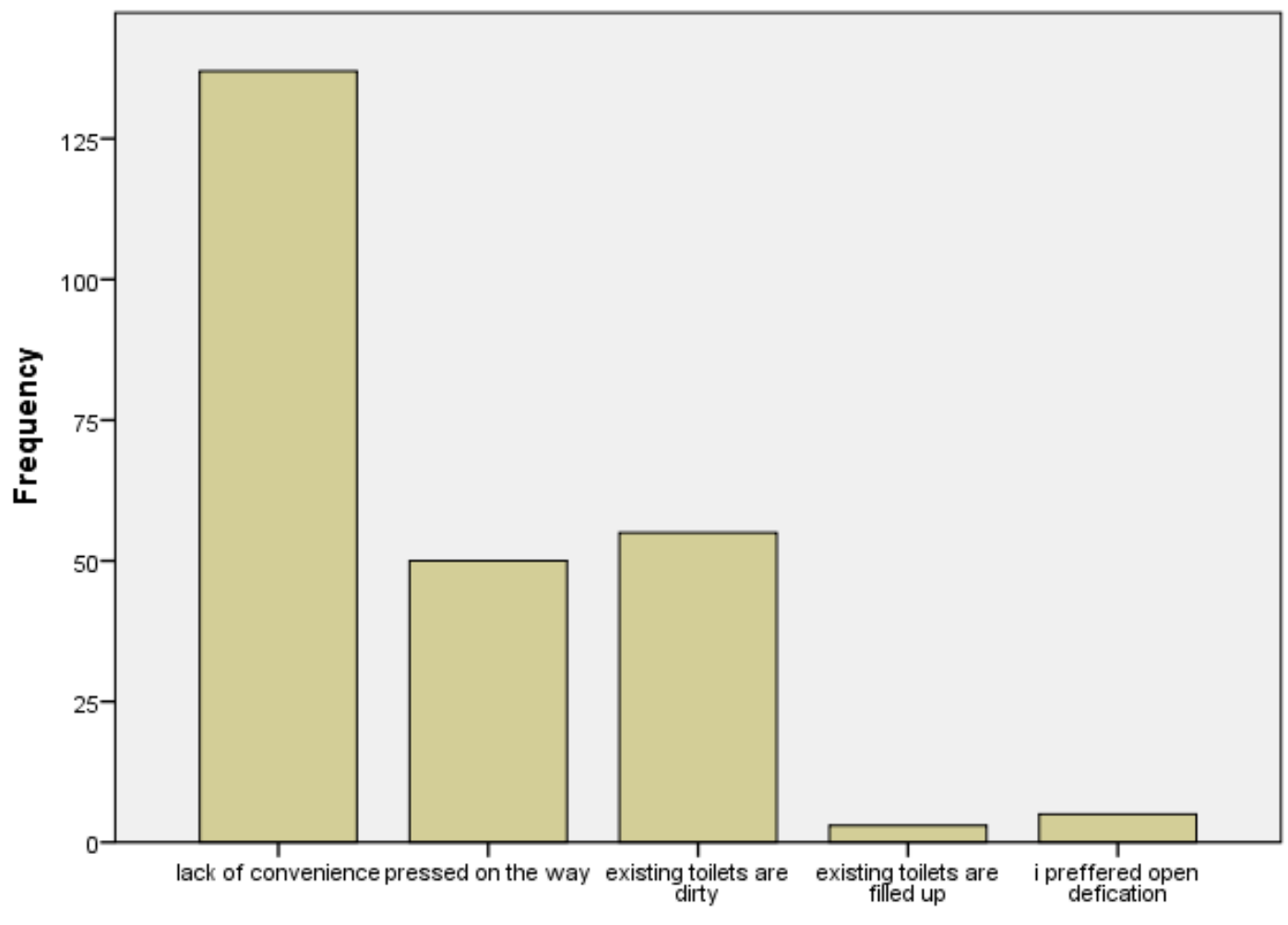

why are you practicing open defecation

Fig. 3: Respondents opinion on why they practiced open defecation

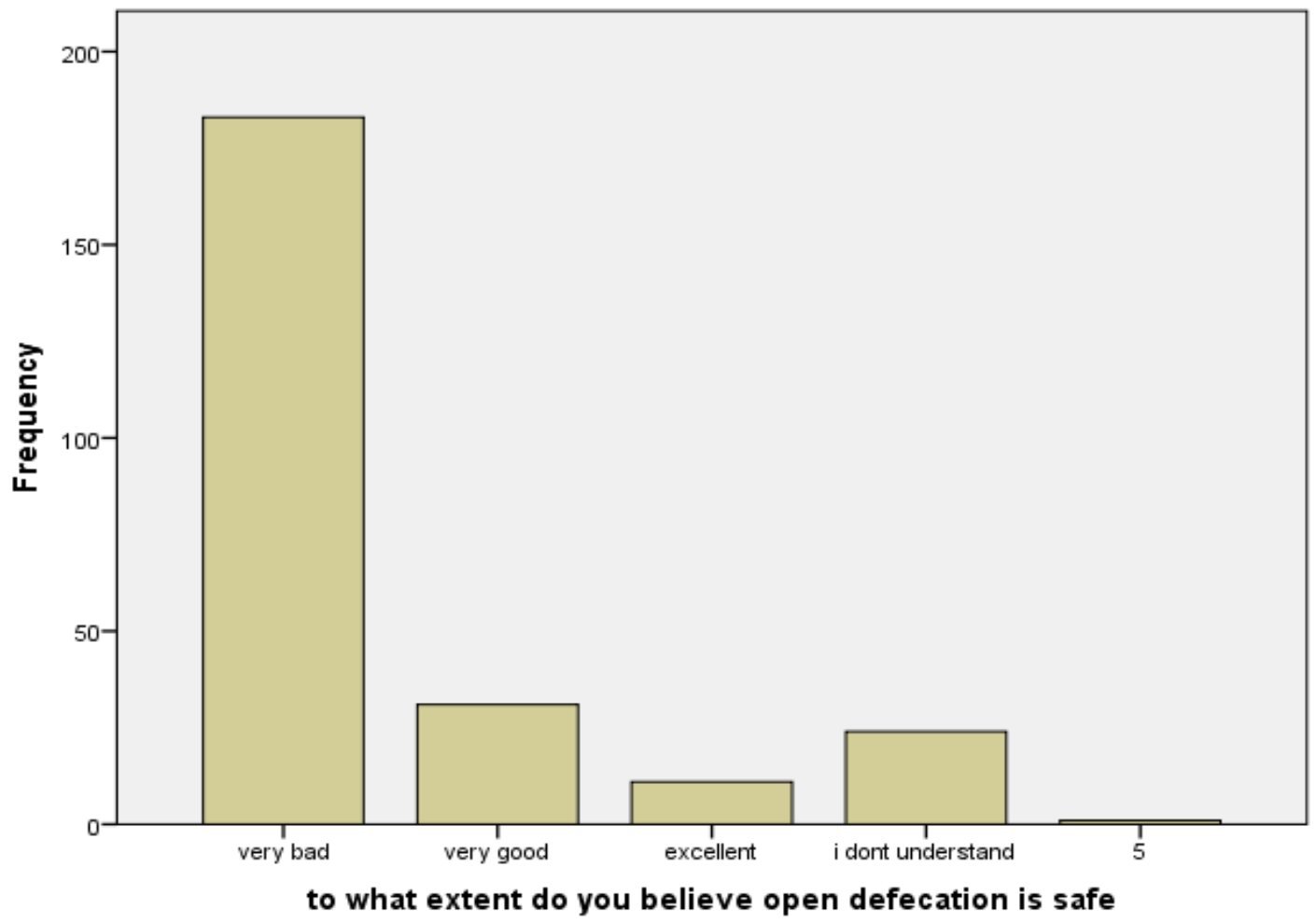

Fig. 4: Respondents opinion on the safety of open defecation

$$
-7 \text { - }
$$




\section{Environmental Studies Journal}

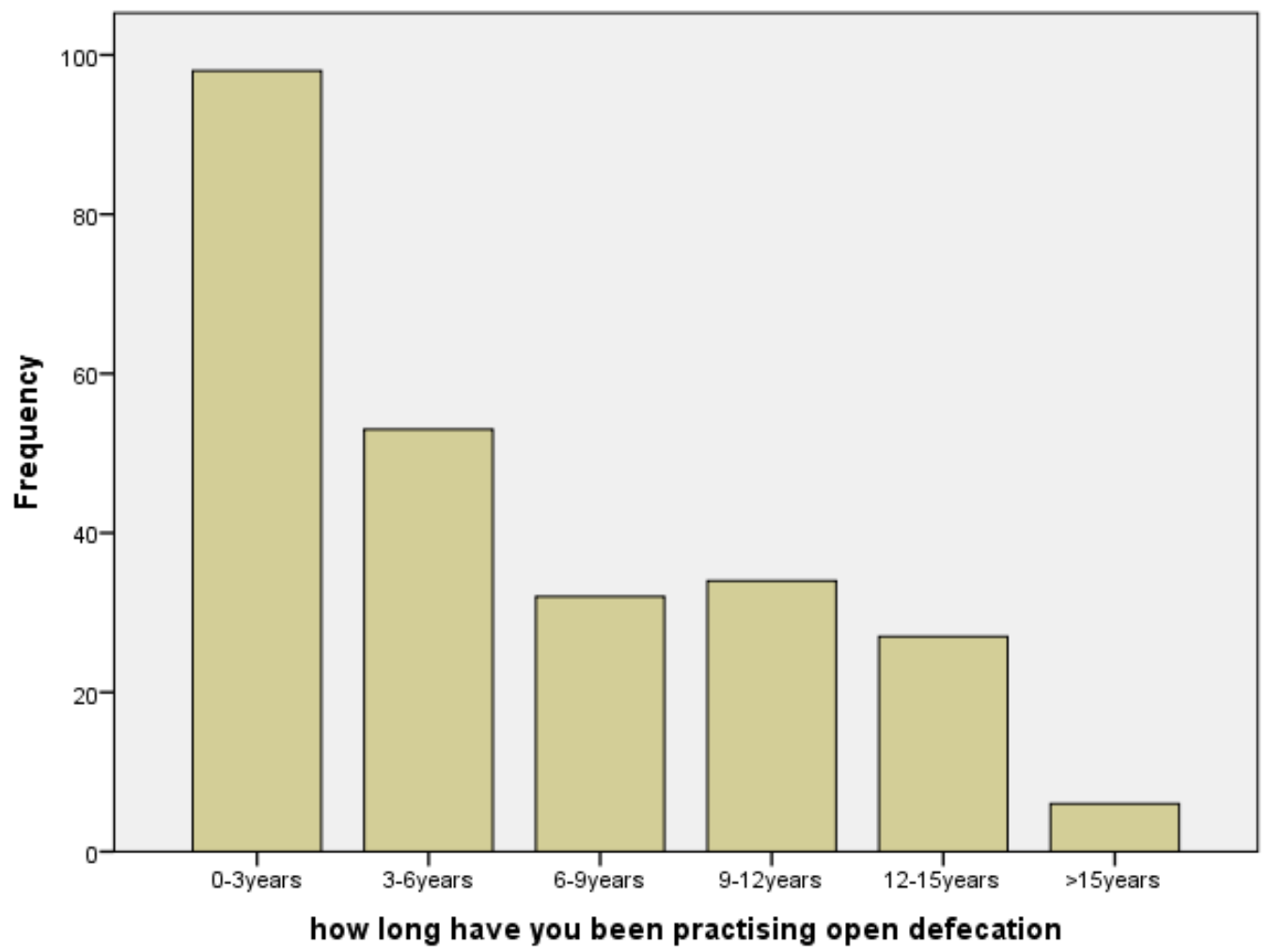

Fig. 5: Respondents opinion on how long they have engaged in open defecation

Poor construction materials such as mud or mat which normally do not last long were being used in constructing latrine facilities in some community. Unpleasant sights such as formation of feces splashes on the latrine floor with stagnant water encourage the practice of open defecation (Busienei et al., 2019). In the result obtain from Fig. 4, 73.2\% of the respondents believed that open defecation is unhealthy. This is close to the findings of Busienei et al. (2019) where $76 \%$ of the respondents were of the opinion that open defecation is unsafe. The practice of open defecation is an environmental health hazards for the people in that community (Gbadegesin and Akintola, 2020). It was reported by Orilomoloye (2015) that the agents of disease or pathogens such as bacteria, viruses, parasites etc. are normally passed out with feces and if not properly disposed, it will be a source of contaminants to ground water, rivers, stream and lagoons. It was also reported by Rose et al. (2015) that one gram of human feces has been found to contain as many as $10,000,000$ viruses, $1,000,000$ bacteria, 1,000 parasite cysts and 100 worm eggs. Open defecation pollutes the environment and affects the quality of drinking water with bad taste making it unfit for drinking purposes (Tambekar et al., 2012). From Fig. 5, 39.2\% of respondents had been practicing open defecation for about 3 years, while $21.2 \%$ of them have been indulging in this act within 3-6 years. 
Reliability Test for Attitude to Open Defecation

Table 3: $\quad$ Reliability statistics

\begin{tabular}{cccc}
\hline & Cronbach's Alpha $(\boldsymbol{\alpha})$ & Mean $\mathbf{\pm}$ S.D & Number of items \\
\hline Attitude to open defecation & 0.733 & $7.46 \pm 2.03$ & 3 \\
\hline
\end{tabular}

Some studies have shown that building and subsidizing toilet facilities is ineffective and unsustainable without behavioral changes in those practicing open defecation (Barnard et al., 2013; Tremoletet al., 2010), as some people have a preference for open defecation over using bucket latrines (Coffey et al., 2014). Some people felt it is difficult to empty full buckets making them reluctant to use the latrines (Coffey et al., 2017; Routray et al., 2015). There is need to intensify efforts towards education, awareness building and peer pressure in the poor communities (Coffey et al., 2014, Hathi et al., 2016 and Crocker et al., 2017).

Table 4: Chi-square for education status of the respondents and usage of modern toilets rather than open defecation

Chi-Square Tests

\begin{tabular}{llll}
\hline & & & Asymp. Sig. (2- \\
& Value & df & sided) \\
\hline Pearson Chi-Square & 11.221 & 5 & .047 \\
Likelihood Ratio & 10.560 & 5 & .061 \\
Linear-by-Linear & 6.698 & 1 & .010 \\
Association & 250 & & \\
N of Valid Cases & & & \\
\hline
\end{tabular}

The relationship between education status of the respondents and usage of modern toilets rather than open defecation in this study was significant with $\chi^{2}$ $(5, N=250)=11.221, p=0.047$. This implies that the level of education a person has could influence his perception of the practice of open defecation as being unhygienic.

The study conducted by Busienei et al. (2019) reported that latrine ownership in the study area of Kenya was largely associated with the respondents' levels of education. It was discovered that household respondents who did not own a latrine were mostly illiterate compared to those who had only primary levels of education. In a similar study conducted in Tanzania, to assess the factors that facilitate the adoption of latrine facility, it was reported that education plays a greater role with people associated with open defecation practice. The respondents who attended school had greater urge of using a latrine facility as compared with those who never attended school (Sara and Graham, 2014). Educational status of mothers plays a greater role in educating the children on the use of latrine and consequently, the bad effects in the practice of open defecation (Yimam et al., 2014). 
Table 5: Independent t-test for attitudes of the respondents towards open defecation and their gender

\begin{tabular}{cllccccc} 
Attitude of & Sex & $\mathbf{N}$ & $\begin{array}{c}\text { Mean } \\
\text { open }\end{array}$ & $\begin{array}{c}\text { Standard } \\
\text { opeviation (S.D) }\end{array}$ & T & Df & Significant \\
nefecation & Male & 168 & 7.27 & 2.220 & -2.138 & 248 & 0.034 \\
\hline
\end{tabular}

Results showed the male gender scores $(M=7.27$, $\mathrm{SD}=2.220)$, female gender scores $(M=7.85, S D=1.500)$ and an independent $\mathrm{t}$-test found this pattern not to be significant, $\mathrm{t}(248)=-2.138, \mathrm{p}<0.05$.

The result shows a significant difference between attitudes of the respondents towards open defecation and their gender for Male $(M=7.27, S D=2.220)$ and Female $(M=7.85, S D=1.500) ; t(248)=-2.138, p=0.034$. This implies that when it comes to open defecation, both male and female think differently. Women are often more vulnerable in the use of open defecation and at risk of experiencing multiple health diseases (Gabriella, 2012). As reported by Strunz et al. (2014),women with poor sanitation facilities are more susceptible to hookworm infestation that can result in maternal anemia which has been directly or indirectly associated to adverse pregnancy complications(Bora et al., 2014). It has also been reported by Corburn and Hildebr (2015) that women with limited or lack of access to toilet facilities suffered predominantly from diarrheal diseases. There is a case study of young girls living in Bengaluru, India who have the habit of defecating in a vacant area beside their poor settlement expressing fears of being exposed while passing the slums, with their struggle of finding privacy to defecate. This has heightened the fear, shame and helplessness that are common with the young girls and women of lower-middle income bracket in countries where open defecation still persists (Pardeshi, 2009). The cultural norms or religious practices also force many women to wait until dusk so that they would not be seen while fulfilling the nature's call of defecating (Pearson and Mcphedran,

2008).

Table 6: Chi-square for accessibility to a hygienic toilet and ending of open defecation among respondents Chi-Square Tests

\begin{tabular}{|c|c|c|c|c|c|c|}
\hline & Value & $\mathrm{df}$ & & $\begin{array}{l}\text { Asymp. Sig. (2- } \\
\text { sided) }\end{array}$ & $\begin{array}{l}\text { Exact Sig. (2- } \\
\text { sided) }\end{array}$ & $\begin{array}{l}\text { Exact Sig. (1- } \\
\text { sided) }\end{array}$ \\
\hline Pearson Chi-Square & 20.489 & & 1 & .000 & & \\
\hline Continuity Correction & 19.128 & & 1 & .000 & & \\
\hline Likelihood Ratio & 20.226 & & 1 & .000 & & \\
\hline Fisher's Exact Test & & & & & .000 & .000 \\
\hline $\begin{array}{l}\text { Linear-by-Linear } \\
\text { Association }\end{array}$ & 20.407 & & 1 & .000 & & \\
\hline $\mathrm{N}$ of Valid Cases & 250 & & & & & \\
\hline
\end{tabular}

In the evaluation of the relationship between accessibility to a hygienic toilet and ending of open defecation among respondents, there was a significant relationship between the variables, $\chi^{2}(1, N$
$=250)=20.489, p<0.05$ as shown in Table 6. This implies that having access to hygienic toilet facilities around these areas where open defecation practices are exhibited could help in ameliorating the menace of open defecation. 


\section{CONCLUSION}

In most developing countries, open defecation is a serious environmental health hazard, even though defecation is a natural urge that everyone has to respond to when the need arises. In a situation where poverty is being reduced and toilet facilities become available, cultural attitudes, social habits, and economic factors can still impair people from the use of infrastructure considered safe and hygienic by environmental health standards due to their usual

ACKNOWLEDGEMENT: Many thanks to all the people that were involved in the administration of the questionnaires.

\section{REFERENCES}

Abubakar, I. R. (2018). Exploring the determinants of open defecation in Nigeria using demographic and health survey data. Science of the Total Environment: 637-638C, 14551465.

https://doi.org/10.1016/j.scitotenv.2018.05.10 4

Abubakar, I. R. and Dano U. L. (2018). Socioeconomic challenges and opportunities of urbanization in Nigeria. In Urbanization and Its Impact on Socio-Economic Growth in Developing Regions,(pp.219-240). https://doi.org/10.4018/978-1-5225-26599.ch011

Alhassan, A and Anyarayor, B.K. (2018). Determinants of adoption of open defecation-free (ODF) innovations: A case study of Nadowli-Kaleo district, Ghana. Journal of Development and Communication Studies, 5(2), 54-69

Barnard, S., Routray, P., Majorin, F., Peletz, R., Boisson, S., Sinha, A. and Clasen, T.F. (2013). Impact of Indian Total Sanitation Campaign on Latrine Coverage and Use: A Cross-Sectional Study in Orissa Three Years following Programme Implementation. PLOS ONE, 8, e71438. ways of life. This study clearly shows that majority of the respondents even though they practice open defecation agreed that it is unhealthy. Also, the results from this study show that there is inadequate access to hygienic toilet facilities in the study area due to poverty, a major factor that contributes to the practice of open defecation. In addition, lack of high statutory education also plays a vital role in what leads to the menace.

FUNDING: The authors did not receive fund from any other source than the one contributed by themselves

CONFLICT OF INTEREST: No conflicts of interest

Bora, R., Sable, C., Wolfson, J, Boro, K. and Rao, R. (2014). Prevalence of anemia in pregnant women and its effect on neonatal outcomes in Northeast India. J Matern Fetal Neonatal Med. 27, 887-91.

Busienei, P.J., Ogendi, G.M. and Mokua, M.A. (2019). Open Defecation Practices in Lodwar, Kenya: A Mixed-Methods Research. Environmental Health Insights 13, 1-13

Cairncross, S., Hunt, C., Boisson, S., Bostoen, K. and Curtis, V. (2010). Water, sanitation and hygiene for the prevention of diarrhea. Int $J$ Epidemiol. 39, 193-205.

Clansen, T., Boison, S., Routray, P., Torondel, B., Bell, M., Cumming, O. Ensink, J., Freeman, M., Jenkins, M., Odagiri, M., Ray, S., Sinha, A., Suar, M. and Schmidt, W.P. (2014). Effectiveness of a rural sanitation program on diarrhea, soil transmitted helminth infection, and child nutrition in Odisha, India: a cluster randomized trial. The Lancet Global Health, 2(11),E645-E653. https://doi.org/10.1016/S2214-109X(14) 70307-9

Coffey, D., Gupta, A., Hathi, P., Khurana, N., Spears, D., Srivastav, N. and Vyas, S. (2014). Revealed

-11 - 
Preference for Open Defecation. Econ. Political Wkly. 49, 43-55.

Coffey, D., Gupta, A., Hathi, P., Spears, D., Srivastav, N. and Vyas, S. (2017). Understanding open defecation in rural India: Untouchability, pollution, and latrine pits. Econ. Polit. Wkly. $52,20$.

Colley, D.G., Bustinduy, A.L., Secor, W.E. and King, C.H. (2014). Human schistosomiasis. Lancet 383, 2253-64.

Connell, K. O. (2014) What Influences Open Defecation and Latrine Ownership in Rural Households? Findings from a Global Review, World Bank, Washington, DC, USA.

Corburn, J. and Hildebrand, C. (2015). Slum sanitation and the social determinants of Women's health in Nairobi, Kenya. I Environ Public Health. 2015, 1-6.

Crocker, J., Saywell, D. and Tracy, J.W. (2017). Sustainability of community-led total sanitation outcomes: Evidence from Ethiopia and Ghana. Int. J. Hyg. Environ. Health, 220, 551-557

Desai, R., McFarlane, C. and Graham, S. (2015). The politics of open defecation: informality, body, and infrastructure in Mumbai. Antipode. 47, 98-120.

Emerson, P.M., Bailey, R.L., Walraven, G.E.L. and Lindsay, SW. (2001). Human and other faeces as breeding media of the trachoma vector Muscasorbens. Med Vet Entomol., 15, 314-20.

Gabriella, Y.C. (2012). Framing water, sanitation, and hygiene needs among female-headed households in periurban Maputo, Mozambique. Am. J. Public. 102, 2.

Gbadegesin, O. A. and Akintola, S. O. (2020). A Legal Approach to Winning the 'Wash' War in Nigeria. European Journal of Environment and Public Health, 4(2), em0043. https://doi.org/10.29333/ejeph/8237

Hathi, P., Spears, D., Coffey, D. and Information, R. (2016). Can collective action strategies motivate behaviour change to reduce open defecation in rural India? Waterlines, 35, 118135

Jain, A., Wagner, A., Snell-Rood, C. and Ray, I. (2020). Understanding Open Defecation in the Age of Swachh Bharat Abhiyan: Agency,
Accountability, and Anger in Rural. Int. J. Environ. Res. Public Health 17, 1384

Jones, H., Fisher, J. and Reed R. (2012). Water and sanitation for all in low-income countries. Proceedings of the Institution of Civil Engineer-Municipal Engineer 165, 167-74.

Nallari, A. (2015). All we want are toilets inside our homes! The critical role of sanitation in the lives of urban poor adolescent girls in Bengaluru, India. Environ Urban. 27, 73-88

Ngwu, U. I. (2017). The practice of open defecation in rural communities in Nigeria: A Call for Social and Behavior Change Communication Intervention. International Journal of Communication Research, 7(3), 201-206.

Njuguna, J. and Muruka, C. (2017). Open defecation in newly created Kenyan counties: a situational analysis. J Health Care Poor Underserved. 28, 71-78.

Orimoloye, E. O., Amadi, C. O. A., Amadi, A. N., Azuamah, Y. C., Nwoke, E. A., Zacchaeus, U. and Dozie, I. N. S. (2015). Assessment of water sanitation and hygiene practices in Ibadan, Nigeria. International Journal of Research (IJR), 2(2), 94-100.

Pardeshi, G. (2009). Women in total sanitation campaign: a case study from Yavatmal District, Maharashtra, India. J Hum Ecol. 25, 79-85.

Pearson, J. and Mcphedran, K. (2008). A literature review of the non-health impacts of sanitation. Waterlines. 27, 48-61.

Peprah, D., Baker, K.K., Moe, C., Robb, K., Wellington, N., Yakubu, H. and Null, C.(2015). Public toilets and their customers in low-income Accra, Ghana. Environ Urban. 27, 589-604. https://doi.org/10.1177/0956247815595918

Rose, C., Parker, A., Jefferson, B. and Carmel, E. (2015). The characterization of feces and urine: $A$ review of literature to inform advanced treatment technology. Critical Reviews in Environmental Science and Technology, 45(17), 1827-1879. https://doi.org/10.1080/10643389.2014.10007 61

Saleem, M., Burdett, T. and Heaslip, V. (2019). Health and social impacts of open defecation on women: a systematic review. BMC Public 
Health

19 ,

158

https://doi.org/10.1186/s12889-019-6423-z

Sara, S. and Graham, J. (2014). Ending open defecation in rural Tanzania: which factors facilitate latrine adoption? Int J Environ Res Public Health.11, 9854-9870

Strunz, E.C., Addiss, D.G., Stocks, M.E., Ogden, S., Utzinger, J. and Freeman, M.C. (2014). Water, sanitation, hygiene, and soil-transmitted helminth infection: a systematic review and meta-analysis.

PLoSMed. https://doi.org/10.1371/journal.pmed.100162 0.

Tambekar, D. H. and Neware, B. B. (2012). Water quality index and multivariate analysis for groundwater quality assessment of villages of rural India. Sci Res Report, 3, 229-235.

Tremolet, S.C.M., Kolsky, P. and Perez, E. (2010). Financing on-site Sanitation for the Poor: A
Six Country Comparative Review and Analysis; The World Bank: Washington, DC, USA

UNICEF/WHO (2015). Progress on sanitation and drinking water - 2015 update and MDG assessment. Geneva: World Health Organization.

World Health Organization (WHO) (2017a). WHO fact sheets for trachoma. Switzerland.. http://www.who.int/mediacentre/factsheets/f s382/en/.

World Health Organization (WHO) (2017b). WHO fact sheets for schistosomiasis. Switzerland. http://www.who.int/mediacentre/factsheets/f s115/en/.

Yimam, Y., Kassahun, G. and Daniel, C. (2014). Latrine utilization and associated factors among people living in rural areas of Denbia district, Northwest Ethiopia, 2013, a cross-sectional study. Pan Afr Med J. 18, 1-10. 